DOI: https://doi.org/10.24127/ajpm.v10i3.3717

\title{
KEMAMPUAN PEMECAHAN MASALAH MAHASISWA CALON GURU MATEMATIKA SEKOLAH MENENGAH BERDASARKAN TAHAPAN POLYA
}

\author{
Sumarni $^{1}$, Darhim ${ }^{2}$, Siti Fatimah ${ }^{3 *}$ \\ 1,2,3* Universitas Pendidikan Indonesia, Bandung, Indonesia \\ ${ }^{1}$ Universitas Kuningan, Kuningan, Indonesia \\ * Corresponding author. Bandung, Indonesia \\ E-mail: marni_39@student.upi.edu; marnie.1205@gmail.com ${ }^{\text {1) }}$ \\ darhim@upi.edu ${ }^{2)}$ \\ sitifatimah@upi.edu $^{3 *)}$
}

Received 114 May 2021; Received in revised form 09 September 2021; Accepted 27 September 2021

\begin{abstract}
Abstrak
Tujuan penelitian ini adalah mendeskripsikan kemampuan pemecahan masalah mahasiswa calon guru sekolah menengah berdasarkan tahapan Polya pada penerapan konsep bangun layang-layang. Penelitian ini merupakan penelitian kualitatif deskriptif, yang dilakukan pada 10 mahasiswa calon guru matematika semester 8, di salah satu perguruan tinggi swasta di Provinsi Jawa Barat, Indonesia. Pengumpulan data dilakukan melalui tes, observasi, dan wawancara. Analisis data dilakukan melalui triangulasi data berdasarkan hasil tes, observasi dan wawancara. Analisis nilai mata kuliah geometri terdapat lima kategori tinggi (KT), tiga kategori sedang (KS) dan dua kategori rendah (KR). Triangulasi data menunjukkan bahwa seluruh mahasiswa calon guru KT, KS, dan KR tidak memeriksa kembali sousi yang diperoleh dalam menyelesaikan soal pemecahan masalah. Mahasiswa KT melakukan tahap penyelesaian maslah sampai pada tahap 3, terdapat dua mahasiswa yang memperoleh solusi yang benar, satu mahasiswa memperoleh solusi yang salah disebabkan kesalahan operasi hitung, dua mahasiswa tidak mempeleh solusi disebabkan kurang teliti dalam membaca soal dan kesulitan operasi hitung. Mahasiswa KS, tahap penyelesaian maslah sampai pada tahap 3, terdapat satu mahasiswa yang memperoleh solusi yang benar, dua mahasiswa memperoleh solusi yang salah disebabkan kesalahan operasi hitung. Mahasiswa KR, satu mahasiswa menyelesaikan masalah sampai pada tahap 3, memperoleh solusi namun solusinya salah disebabkan kesalahan operasi hitung, satu mahasiswa tidak memahami soal yang diberikan dan lupa konsep yang harus digunakan dalam menyelesaikan masalah.
\end{abstract}

Kata kunci: Calon guru matematika; pemecahan masalah; tahapan Polya.

\begin{abstract}
The purpose of this study was to describe the problem-solving abilities of prospective high school teachers based on the Polya stages. This research is a descriptive qualitative research, which was conducted on 10 prospective mathematics teachers who will conduct research on the topic of rectangles, at one of the private universities in West Java Province, Indonesia. Data collection was carried out through tests, observations, and interviews. Data analysis was performed through data triangulation based on test results, observation and interviews. Analysis of the value of the geometry course there is five high categories (KT), three medium categories $(K S)$, and two low categories $(K R)$. Data triangulation shows that all prospective $K T$, $K S$, and $K R$ teacher candidates do not re-examine the solutions obtained in solving problem-solving problems. KT students carried out the problem-solving stage until stage 3. Two students got the correct solution, one student got the wrong solution due to arithmetic operations errors, two students did not get the solution due to lack of accuracy in reading the question, and difficulty arithmetic operations. KS students, the problem-solving stage reaches stage 3. There is one student who gets the correct solution, two students get the wrong solution due to arithmetical errors. KR students, one student solved the problem up to stage 3, he got the solution, but the solution was incorrect due to an arithmetic operation error, one student did not understand the problem given and forgot the concepts that must use in solving the problem.
\end{abstract}

Keywords: Phase Polya; problem solving; prospective mathematics teacher.

This is an open access article under the Creative Commons Attribution 4.0 International License 
DOI: https://doi.org/10.24127/ajpm.v10i3.3717

\section{PENDAHULUAN}

Terdapat dua komponen penting dalam persiapan guru, yaitu pengetahuan guru tentang materi yang diajar dan pengetahuan keterampilan dalam mengajarkan materi tersebut (National Council for Accreditation of Teacher Education (NCATE), 2008). Pengetahuan guru tentang materi yang akan diajar dinamakan mathematics content knowledge (MCK) (Leong, Chew, \& Rahim, 2015; Sumarni, Darhim, \& Fatimah, 2020; Sumarni, Darhim, Fatimah, Widodo, \& Riyadi, 2019). MCK dalam konsep kognitif terdiri atas tiga komponen yaitu knowing, applying dan reasoning (Tatto \& Senk, 2011). Applying yang merupakan salah satu komponen dari MCK adalah kemampuan menerapkan konsep untuk pemecahan masalah (Tatto et al., 2013).

Menurut Cockcroft pemecahan masalah adalah jantung dari pendidikan matematika (Barham, 2019). Pernyataan tersebut menekankan pentingnya kemampuan pemecahan masalah bagi siswa. Pemecahan masalah didefinisikan sebagai suatu proses di mana siswa menggabungkan unsurunsur pengetahuan, aturan, teknik, keterampilan dan konsep yang telah dipelajari sebelumnya untuk memberikan solusi bagi situasi baru (Barham, 2019).

Mahasiswa calon guru matematika harus cukup mendapatkan kesempatan mengembangkan kemampuannya dalam pemecahan masalah (Saputro \& Sumarni, 2017; Sumarni, Darhim, \& Siti, 2019). Hal ini karena dalam tugasnya nanti ketika menjadi guru adalah membimbing siswa belajar untuk memecahkan masalah matematika (Iqbal \& Akbar, 2020). Lebih lanjut menurut (Iqbal \& Akbar, 2020) mengajarkan bagaimana menyelesaikan masalah merupakan kegiatan guru untuk memberikan tantangan atau motivasi kepada para siswa agar mereka mampu memahami masalah tersebut, tertarik untuk memecahkannya, mampu menggunakan semua pengetahuannya untuk merumuskan strategi dalam memecahkan masalah, melaksanakan strategi yang dipilih, dan menilai apakah jawaban yang diperoleh benar atau tidak.

Mengingat pentingnya kemampuan pemecahan masalah bagi pendidikan matematika (Barham, 2019) dan pemecahan masalah juga merupakan komponen dari pengetahuan mengajar guru (Tatto \& Senk, 2011). Mahasiswa calon guru sekolah menengah juga harus memiliki kemampuan pemecahan masalah. Selain itu, Measurment (pengukuran) merupakan salah satu aspek konten matematika yang harus dikuasai oleh mahasiswa calon guru (Tatto et al., 2013). Sehingga mahasiswa calon guru harus memiliki kemampuan pemecahan masalah dalam topik geometri salah satunya materi segiempat.

Beberapa penelitian terdahulu telah mengeksplorasi kemampuan pemecahan masalah mahasiswa calon guru (Masfingatin, Murtafiah, \& Krisdiana, 2018; Nugroho \& Dwijayanti, 2019; Pratiwi, Santi, \& Maharani, 2019; Yayuk \& Husamah, 2020). Penelitian (Masfingatin et al., 2018) menganalisis kemampuan pemecahan masalah calon guru pada topik pembuktian teorema geometri. Penelitian (Nugroho \& Dwijayanti, 2019), menganalisi kemampuan pemecahan masalah calon guru pada topik program linier. Penelitian (Pratiwi et al., 2019) menganalisis kemampuan pemecahan masalah calon guru sekolah dasar pada topik pecahan, 
berdasarkan tahapan pemecahan masalah Polya. Penelitian (Yayuk \& Husamah, 2020) mengeksplorasi kemampuan pemecahan masalah mahasiswa calon guru SD berdasarkan tahapan polya.

Berdasar beberapa penelitian terdahulu, belum ada penelitian yang menganlisis kemampuan pemecahan masalah mahasiswa calon guru sekolah menengah berdasar tahapan Polya. Oleh karena itu, pada penelitian ini peneliti bertujuan mengkaji kemampuan pemecahan masalah mahasiswa calon guru sekolah menengah berdasarkan tahapan Polya pada penerapan konsep bangun layang-layang. Melalui penelitian ini diharapkan dapat memberikan gambaran kemampuan pemecahan masalah mahasiswa calon guru matematika tingkat mengengah berdasarkan tahapan Polya. Sehingga bisa menjadi bahan pertimbangan dalam upaya peningkatan kompetensi mahasiswa calon guru sekolah menengah.

\section{METODE PENELITIAN}

Penelitian ini merupakan penelitian kualitatif deskriptif dengan pendekatan studi kasus. Penelitian kualitatif deskriptif dengan pendekatan studi kasus digunakan untuk menggali secara mendalam tentang kemampuan pemecahan masalah mahasiswa calon guru, guna mendapatkan informasi tentang kemampuan pemecahan masalah pada topik segiempat, khususnya penerapan konsep luas layang-layang.

Penelitian ini dilakukan di salah satu perguruan tinggi swasta di Provinsi Jawa Barat, Indonesia. Subjek penelitian ini adalah 10 mahasiswa calon guru matematika semester 8 . Dalam penelitian ini subjek diberi kode M1, M2, ..., M10.
Pengumpulan data dilakukan melalui tes, observasi, dan wawancara. Mahasiswa calon guru diberi instrumen tes, kemudian jawaban dianalisis. Selanjutnya dilakukan observasi skor mata kuliah geometri bidang. terdapat hubungan antara perfomance akademik dengan kemampuan berpikir tingkat tinggi (salah satunya kemampuan pemecahan masalah) (Tanujaya, Mumu, \& Margono, 2017). Selanjutnya, wawancara tentang pegalaman belajar topik segiempat di sekolah dan di universitas. Berdasarkan hasil tes, observasi dan wawancara, kami menganalisis kemampuan pemecahan masalah mahasiswa calon guru.

Prosedur penelitian ini dilakukan dengan langkah-langkah sebagai berikut: 1) memberikan tes problem solving, 2) menganalisis jawaban, 3) observasi dan wawancara, 4) triangulasi data.

Tes dilakukan dengan instrumen menggunakan satu soal aspek applying (menerapkan konsep untuk pemecahan masalah) dari instrumen tes MCK yang telah divalidasi oleh ahli. Soal tes pemecahan masalah yang diberikan adalah sebagai berikut.

Sebuah layang-layang $A B C D$, dengan panjang diagonal $D B=a \mathrm{~cm}$, panjang diagonal $A C=3 a \mathrm{~cm}$. Tentukan panjang diagonal $D B$ dan $A C$ layanglayang tersebut jika luas layang-layang $864 \mathrm{~cm}^{2}$.

Hasil observasi terhadap skor mata kuliah geometri bidang. terdapat 5 mahasiswa calon guru (M1, M2, M3, m4, dan M5) dengan nilai geometri bidang A, 3 mahasiswa calon guru (M6, M7, dan M8) dengan nilai B dan 2 mahasiswa calon guru (M9 dan M10) dengan nilai C. Berdasarkan nilai geometri bidang, maka nilai A 
dikategorikan sebagai kategori tinggi, nilai $\mathrm{B}$ dikategorikan sedang dan nilai $\mathrm{C}$ dikategorikan rendah. Jawaban setiap mahasiswa calon guru pada masing masing kategori nilai geometri bidang, dianalisis untuk mengetahui tahapan pemecahan masalah berdasarkan Polya (lihat Tabel 1). Kemudian wawancara dilakukan untuk memperoleh informasi pengalaman belajar topik segiempat di sekolah dan di universitas dari subjek penelitian, perwakilan dari subjek kategori tinggi, sedang dan rendah.

Analisis data dilakukan melalui triangulasi data berdasarkan hasil tes, observasi dan wawancara. Berdasarkan triangulasi data, diperoleh informasi kemampuan pemecahan masalah mahasiswa calon guru, pada topik segiempat khususnya konsep luas layang-layang.

Tabel 1. Tahapan pemecahan masalah berdasarkan Polya

\begin{tabular}{cl}
\hline Fase & \multicolumn{1}{c}{ Deskripsi } \\
\hline Memahami & fase memahami tentang apa masalahnya dan apa yang ditanyakan. Ini \\
masalahnya & adalah fase pertama dan paling signifikan untuk solusi. \\
Menyusun & fase penentuan strategi untuk menyelesaikan masalah. Pengetahuan \\
rencana & tentang strategi penting dalam fase ini. \\
Menjalankan & fase untuk menerapkan strategi, metode, dan teknik yang dipilih. Pada \\
rencana & fase ini pengetahuan tentang topik dan algoritma menjadi penting. \\
Melihat & fase memeriksa solusi dan memeriksa apakah hasilnya logis dan \\
kembali & benar. Mengadaptasi solusi untuk situasi serupa juga penting dalam \\
masalahnya & fase ini
\end{tabular}

(Usta, 2020)

\section{HASIL DAN PEMBAHASAN}

Dalam penyelesaian soal pemecahan masalah yang diberikan pada penelitian ini, mahasiswa harus menguasai konsep diagonal dan luas layang-layang. Selain itu, diperlukan keterampilan doing mathematics yang dalam tahap menjalankan rencana. Berikut ditampilkan hasil kerja soal applying (menerapkan konsep luas layang layang untuk memecahkan masalah) mahasiswa calon guru, untuk setiap kategori.

a. Hasil kerja pemecahan masalah mahasiswa dengan nilai mata kuliah geometri bidang kategori tinggi

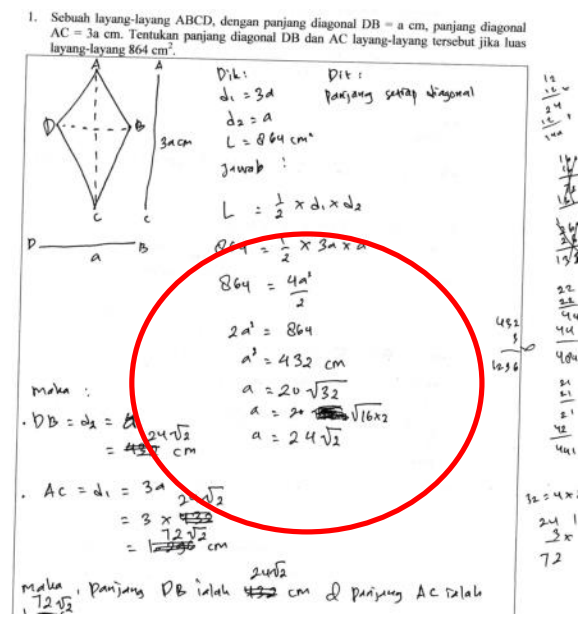

Gambar 1. Hasil kerja pemecahan masalah M1

Tampilan hasil kerja dari M1, yang merupakan mahasiswa dengan nilai mata kuliah geometri bidang kategori tinggi dapat dilihat pada Gambar 1. 
DOI: https://doi.org/10.24127/ajpm.v10i3.3717

M1 merupakan mahasiswa dengan nilai mata kuliah geometri bidang kategori tinggi. Berdasarkan Gambar 2. M1 memahami tentang apa masalahnya dan apa yang ditanyakan, mampu menentukan strategi untuk menyelesaikan masalah. Mampu menjalankan rencana. Sehingga dapat memperoleh jawaban dari permasalahan yang diajukan. Namun terdapat operasi hitung bentuk aljabar pada tahap menjalankan rencana (ditandai dengan warna merah). Selain itu, M1 tidak memeriksa solusi apakah hasilnya logis dan benar.

Selanjutnya berikut hasil wawancara peneliti dengan M1 terkait pengalaman belajar materi geometri di tingkat sekolah dan perguruan tinggi.

$P: \begin{aligned} & \text { Ceritakan bagaimana } \\ & \text { pengalaman saat belajar } \\ & \text { segiempet di sekolah. }\end{aligned}$

$M 7$ : Dulu belajar segiempat di SMP, guru yang nerangin, kasih tau rumus bangun bangunnya, gurunya kasih contoh soal, terus kita suruh ngerjain soal-soal latihan

$P$ : Soal-soal latihannya seperti apa bentuk soalnya

M1 : Ngasih soal bentuknya soal essay bu

$P \quad$ : soal yang diberikan langsung dalam bentuk gambar bangun, atau bentuk soal cerita?

M1 : Ada yang langsung bentuk gambar bangunnya, ada juga yang soal cerita.

$P \quad: \quad O k$, terus kalau di universitas ketika belajar topik segiempat bagaimana?

M1 : Belajarnya segiempat itu pas di mata kuliah geometri bidang bu, pake buku yang buku bahasa inggris, belajarnya diskusi kelompok, terus presentasi.
$P \quad:$ Tugas soal-soal yang harus dikerjakan itu seperti apa?

M1 : Soal soal yang dari buku yang bahasa inggrisnya itu bu, ada yg pembuktian, ada yang perhitungan, soal cerita gitu sih bu

$P \quad$ : Setelah mengerjakan soal dan dapat hasilnya, cek lagi tidak hasil pengerjaannya itu benar atau tidak?

M1 : Pas mengerjakan soal ini, tidak cek bu. tapi biasanya kalau ada waktu paling ngecek proses hitungan bener apa tidak

Berdasarkan wawancara pembelajaran yang pernah dilalui M1 kurang memberikan pengalaman belajar yang memfasilitasi M1 melakukan pemecahan masalah. Karena pembelajaran secara ekspositori dan menggunakan buku teks. Meskipun soal yang diberikan beragam ada yang berupa soal cerita yang identik dengan soal pemecahan masalah.

Dalam menyelesaikan soal yang diberikan M1 tidak memeriksa kembali solusi dari pemecahan masalah yang diperoleh. Berdasarkan wawancara, M1 biasanya mengecek dengan memeriksa perhitungan jika ada waktu lebih.

M1 termasuk kategori mahasiswa dnegan nilai geometri tinggi. Namun karena M1 tidak melakukan tahap 4, sehingga M1 tidak menyedari salah dalam operasi aljabar menyebabkan solusi penyelesaian masalah yang diperoleh tidak tepat.

Berdasarkan temuan ini kita dapat melihat pentngnya tahap mengecek kembali solusi (tahap 4 pada tahapan pemecahan masalah berdasarkan Polya). Karena tahap 4 berfungsi untuk memeriksa apakah solusi yang diperoleh logis dan benar atau tidak, 
DOI: https://doi.org/10.24127/ajpm.v10i3.3717

merupakan tahap akhir yang penting. Ketika mahasiswa tidak melakukan tahap 4, mahasiswa tidak mengetahui apakah solusi yang diperoleh dari tahap 3 salah atau benar. Selain itu, berdasarkan temuan ini, pentingnya penguasaan konsep operasi hitung itu penting untuk menyelesaiakan masalah pada topik geometri. Selanjutnya, tampilan dari hasil pengerjaan M2 dapat dilihat pada Gambar 2.

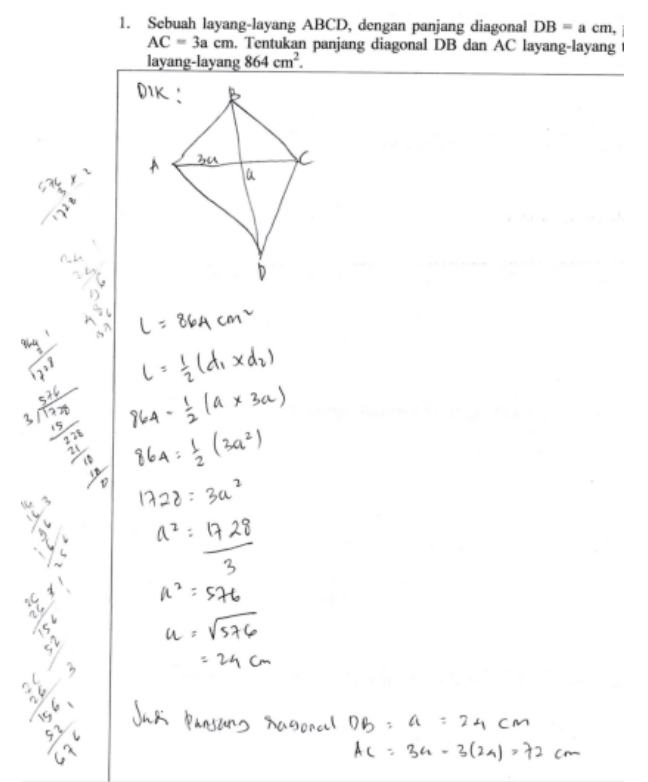

Gambar 2. Hasil kerja pemecahan masalah M2

M2 merupakan satu dari 10 mahasiswa subjek penelitian dengan nilai mata kuliah geometri bidang kategori tinggi. Berdasarkan Gambar 2., M2 memahami tentang apa masalahnya dan apa yang ditanyakan, mampu menentukan strategi untuk menyelesaikan masalah. Mampu menjalankan rencana dan memperoleh jawaban dari permasalahan yang diajukan dengan tepat. Namun, mahasiswa tidak memeriksa solusi apakah hasilnya logis dan benar. Selanjutnya, tampilan dari hasil pengerjaan M3 dapat dilihat pada Gambar 3.

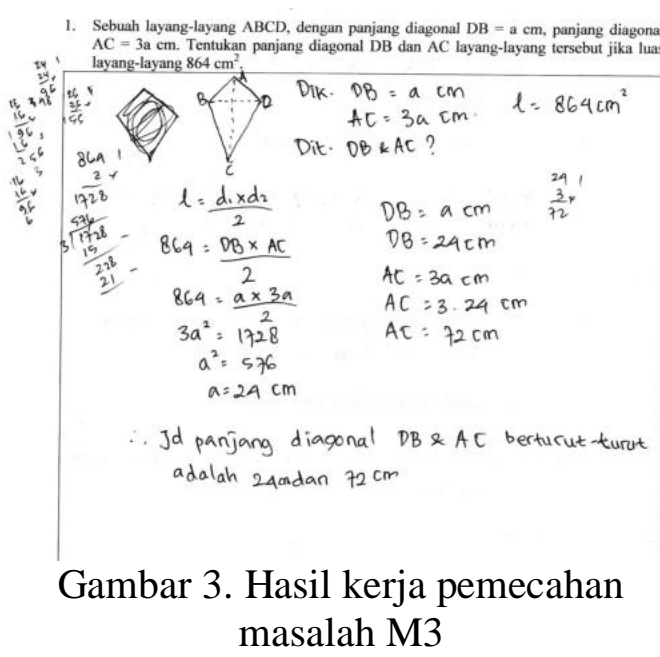

M3 merupakan satu dari 10 mahasiswa subjek penelitian dengan nilai mata kuliah geometri bidang kategori tinggi. Berdasarkan Gambar 3., M3 memahami tentang apa masalahnya dan apa yang ditanyakan, mampu menentukan strategi untuk menyelesaikan masalah. Mampu menjalankan rencana dan memperoleh jawaban dari permasalahan yang diajukan dengan tepat. Namun, mahasiswa tidak memeriksa solusi apakah hasilnya logis dan benar. Adapun hasil dari pengerjaan subjek 4 (M4) dapat dilihat seperti pada Gambar 4.

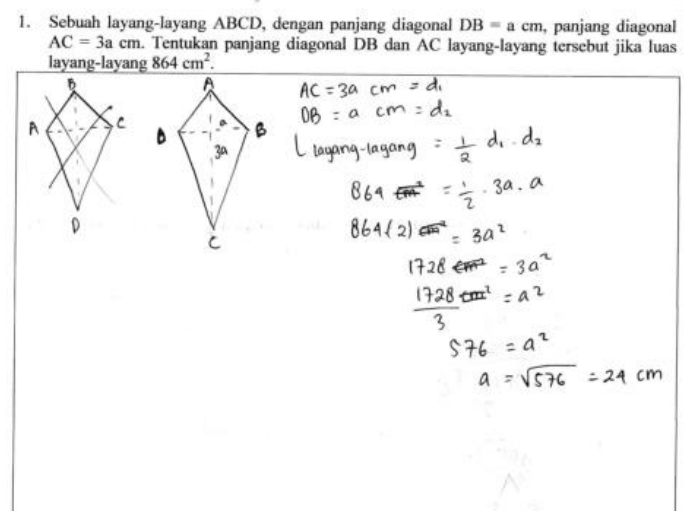

Gambar 4. Hasil kerja pemecahan masalah M4 (Subjek 4) 
M4 merupakan satu dari 10 mahasiswa subjek penelitian dengan nilai mata kuliah geometri bidang kategori tinggi. Berdasarkan Gambar 4, M4 mampu memahami tentang apa masalahnya dan apa yang ditanyakan, mampu menentukan strategi untuk menyelesaikan masalah. Mampu menjalankan rencana, namun belum memperoleh jawaban dari permasalahan yang diajukan dengan tepat (tidak menyesalaikan hingga diperoleh diagonal AC dan DB). Selain itu, mahasiswa tidak memeriksa solusi apakah hasilnya logis dan benar. Terakhir, hasil dari M5 dapat dilihat pada Gambar 5.

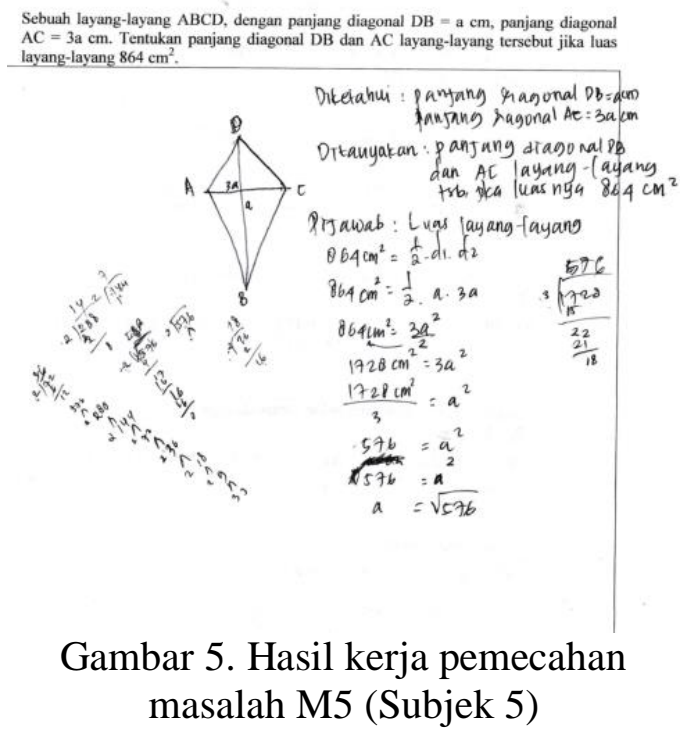

M5 merupakan mahasiswa subjek penelitian dengan nilai mata kuliah geometri bidang kategori tinggi. Berdasarkan Gambar 5., M3 memahami tentang apa masalahnya dan apa yang ditanyakan, serta mampu menentukan strategi untuk menyelesaikan masalah. M5 mampu menjalankan rencana, namun belum memperoleh solusi dari permasalahan yang ditanyakan. Ada kemungkinan mahasiswa kesulitan dalam menentukan hasil akar dari 576.

\section{b. Hasil kerja pemecahan masalah mahasiswa dengan nilai mata kuliah geometri bidang kategori sedang}

Subjek penelitian yang masuk dalam kategori sedang adalah M6, M7, dan M8. Hasil atau tampilan pertama adalah hasil dari M6 yang dapat dilihat pada Gambar 6.

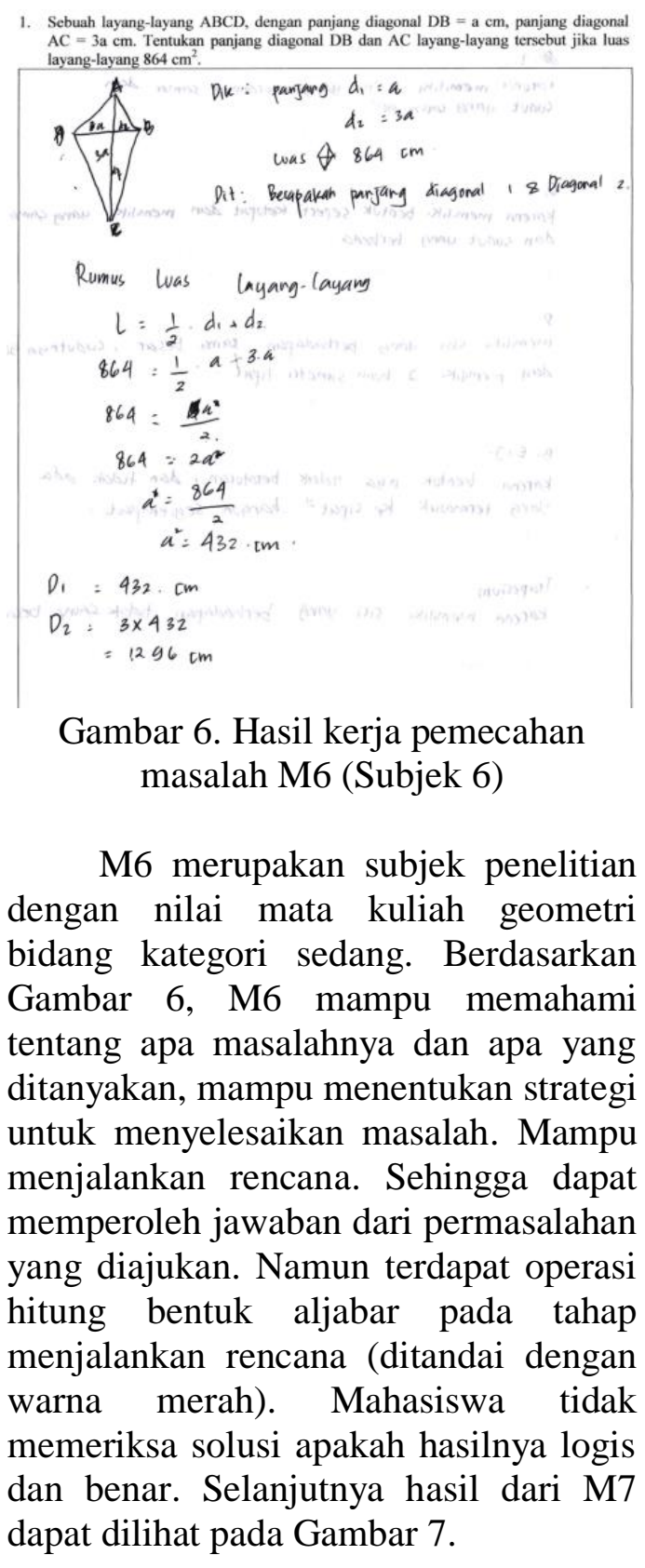


DOI: https://doi.org/10.24127/ajpm.v10i3.3717

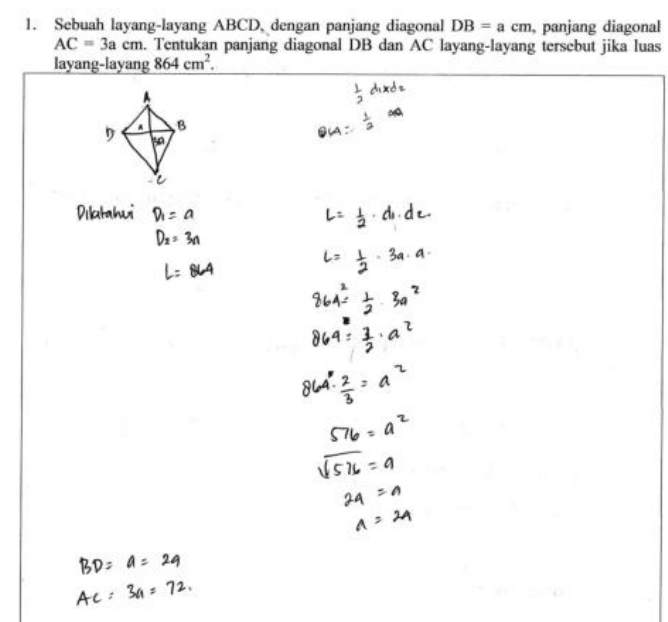

Gambar 7. Hasil kerja pemecahan masalah M7 (Subjek 7)

M7 merupakan mahasiswa dengan nilai mata kuliah geometri bidang kategori sedang. Berdasarkan Gambar 3., M7 mampu memahami tentang apa masalahnya dan apa yang ditanyakan, mampu menentukan strategi untuk menyelesaikan masalah. M7 mampu menjalankan rencana dan memperoleh jawaban dari permasalahan yang diajukan dengan tepat. Namun, M7 tidak memeriksa solusi apakah hasilnya logis dan benar.

\begin{tabular}{|c|c|}
\hline$P$ & $\begin{array}{l}\text { Ceritakan bagaimana } \\
\text { pengalaman saat belajar segi } \\
\text { empat di sekolah. }\end{array}$ \\
\hline$M 7$ & $\begin{array}{lrr}\text { Gurunya nerangin } & \text { rumus } \\
\text { bangun- bangunnya, ngasih } \\
\text { contoh soal, terus kita dikasih } \\
\text { soal-soal latihan, ya masoh } \\
\text { ceramah gitu } \\
\text { pembelajarannya }\end{array}$ \\
\hline$P$ & $\begin{array}{l}\text { Soal-soal latihannya sepert } \\
\text { apa bentuk soalnya }\end{array}$ \\
\hline$M 7$ & $\begin{array}{l}\text { soal-soal sama seperti yang } \\
\text { contohnya, paling ganti } \\
\text { angkanya aja. }\end{array}$ \\
\hline$P$ & $\begin{array}{l}\text { soal yang diberikan langsung } \\
\text { dalam bentuk gambar bangun, } \\
\text { atau bentuk soal cerita? }\end{array}$ \\
\hline$M 7$ & $\begin{array}{l}\text { Ada yang langsung gambar } \\
\text { bangun, ada yang soal cerita. }\end{array}$ \\
\hline$P$ & Ok, terus kalau di universitc \\
\hline
\end{tabular}

ketika belajar topik segiempat bagaimana?

M7 : Belajarnya segiempat itu pas di mata kuliah geometri bidang dan kapselmat 1 bu. Pas geometri bidang itu pake buku bahasa inggris, belajarnya diskusi, terus presentasi, nerjemahin yaitu sih bu yang bingung. Pas kapselmat bukunya pake buku-buku BSE bu.

$P \quad$ : Tugas soal-soal yang harus dikerjakan itu seperti apa?

M7 : Tugas soal yang dari bukunya bu, susah-susah bu kalau yang dari bahasa inggris apalagi yang pembuktian. Kalau yang kapselmat kan dari buku BSE jadi ya lumayan bisa.

$P \quad:$ Biasanya setelah mengerjakan soal dan dapat hasilnya, cek lagi tidak hasil pengerjaannya itu benar atau tidak?

M7 : Kalau waktunya masih ada ya cek lagi bu, cek perhitungan bener apa engga.

Berdasarkan wawancara pembelajaran yang pernah dilalui, M7 kurang memperoleh pengalaman belajar yang memfasilitasi untuk melakukan pemecahan masalah karena pembelajaran secara ekspositori dan menggunakan buku teks. Meskipun soal yang diberikan tidak hanya perhitungan dalam bangun datar, ada yang berupa soal cerita yang identik dengan soal pemecahan masalah.

Dalam menyelesaikan soal yang diberikan, M7 tidak memeriksa kembali solusi yang diperoleh, meskipun solusi yang diperoleh sudah tepat. Berdasarkan wawancara, M7 biasanya mengecek dengan memeriksa perhitungan jika ada waktu lebih. 
Dalam pemecahan masalah Tahap 4 berfungsi untuk memeriksa apakah solusi yang diperoleh logis dan benar atau tidak, merupakan tahap akhir yang penting. Hendaknya setelah memperoleh hasil solusi berdasarkan tahap 3 mahasiswa calon guru memeriksa dengan memsubstitusi hasil diagonal 1 dan diagonal 2 dari layang layang menggunakan rumus luas layang layang dan memeriksa apakah hasil perhitungan luas layang layang dengan diagonal 1 dan diagonal 2 dari hasil solusi sesuai atau belum.

Berikutnya, disajikan hasil pengerjaan oleh M8 seperti pada Gambar 8.

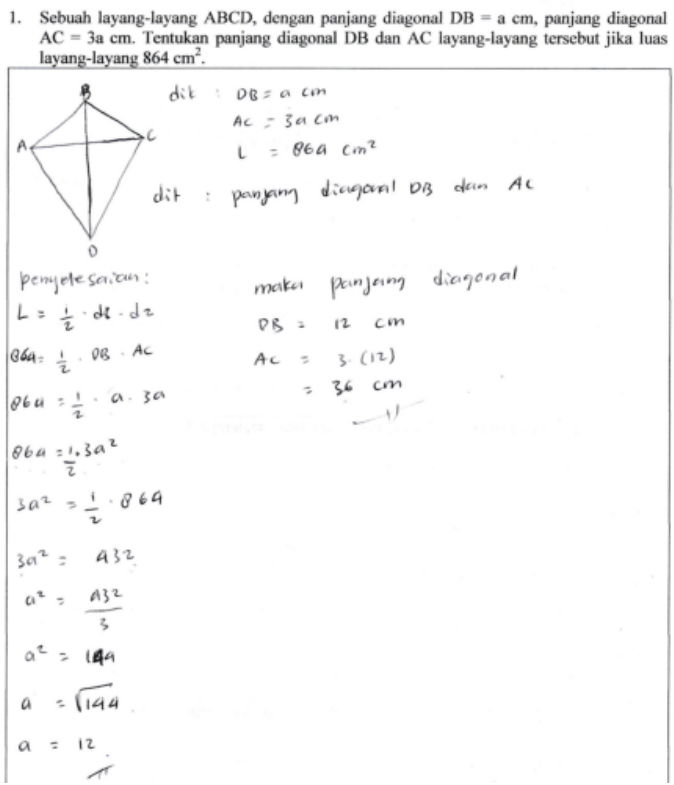

Gambar 8. Hasil kerja pemecahan masalah M8 (Subjek 8)

M8 merupakan mahasiswa calon guru dengan nilai mata kuliah geometri bidang kategori sedang. Berdasarkan Gambar 8., M8 mampu memahami tentang apa masalahnya dan apa yang ditanyakan, mampu menentukan strategi untuk menyelesaikan masalah. Mampu menjalankan rencana. Sehingga dapat memperoleh jawaban dari permasalahan yang diajukan. Namun terdapat operasi hitung pada tahap menjalankan rencana (ditandai dengan warna merah). Mahasiswa tidak memeriksa solusi apakah hasilnya logis dan benar.

\section{c. Hasil kerja pemecahan masalah mahasiswa dengan nilai mata kuliah geometri bidang kategori rendah}

Hasil kerja pemecahan masalah untuk mahasiswa dengan kategori sedang diwakili oleh M9 dan M10. Adapun hasil pengerjaan oleh M9 dapat dilihat pada Gambar 9.

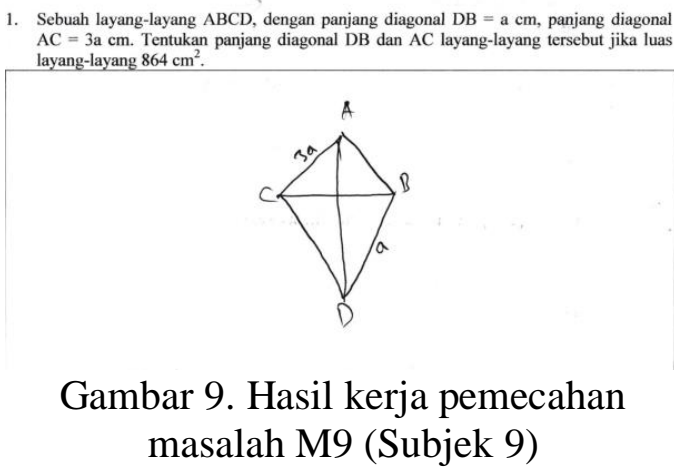

M9 merupakan mahasiswa calon guru dengan nilai mata kuliah geometri bidang kategori rendah. Berdasarkan Gambar 9, mahasiswa tidak memahami masalah, mahasiswa ada kemungkinan tidak memahami diagonal pada layanglayang, lupa rumus luas layang-layang. Sehingga merepresentasikan permasalahan dalam bentuk gambar yang salah.

Berikut hasil wawancara terkait pengalaman belajar topik segiempat di sekolah dan di universitas serta konfirmasi hasil pengerjaan soal yang dilakukan oleh M9.

$\begin{aligned} P: & \text { Ceritakan bagaimana } \\ & \text { pengalaman saat belajar } \\ & \text { segiempet di sekolah. } \\ \text { M9: } & \text { Waktu di sekolah guru yang } \\ & \text { nerangin, kasih rumus-rumus, }\end{aligned}$


DOI: https://doi.org/10.24127/ajpm.v10i3.3717

ngasih contoh soal, terus kita dikasih soal-soal latihan

$P \quad:$ Soal-soal latihannya seperti apa bentuk soalnya

M9 : Sama, mirip kayak contoh soal

$P \quad$ : Soal yang diberikan langsung dalam bentuk gambar bangun, atau bentuk soal cerita?

M9 : Ada yang langsung bentuk gambar bangunnya, ada juga soal cerita bu.

$P \quad: \quad$ Ok, terus kalau di universitas ketika belajar topik segiempat bagaimana?

M9 : Pas geometri bidang bu, pake buku yang buku bahasa inggris, belajarnya diskusi kelompok, terus presentasi.

$P \quad$ : Tugas soal-soal yang harus dikerjakan itu seperti apa?

M9 : Soal soal yang dari buku yang bahasa inggrisnya itu bu, harus ngartiin soalnya dulu bu.

$P \quad:$ Ok, masih inget tidak rumus luas layang-layang?

M9 : Lupa bu, makanya yang soal layang-layang itu engga bisa ngerjain.

$P \quad:$ Yang $A$ inget tentang luas layang layang apa?

M9 : Ingetnya kalau luas itu hasil kali sisi sisi, bu.

Berdasarkan wawancara pembelajaran yang pernah dilalui M9 kurang memberikan pengalaman belajar yang memfasilitasi M9 melakukan pemecahan masalah. Karena pembelajaran secara ekspositori dan menggunakan buku teks. Meskipun soal yang diberikan beragam ada yang berupa soal cerita yang identik dengan soal pemecahan masalah.

M9 tidak dapat memahami soal dengan baik karena M9 lupa dengan konsep diagonal dan rumus luas layang layang. Berdasarkan temuan ini pentingnya pembelajaran yang bermakna agar peserta didik tidak lupa dengan konsep dan rumus yang dipelajari.

Selanjutnya, hasil dari pengerjaan oleh M10 dapat dilihat pada Gambar 10.

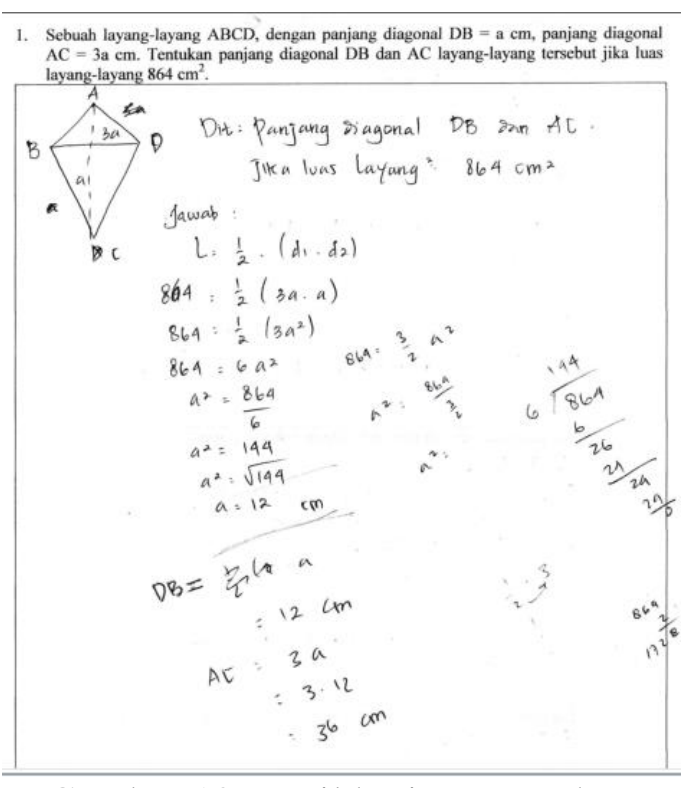

Gambar 10. Hasil kerja pemecahan masalah M10 (Subjek 10)

M10 merupakan mahasiswa calon guru dengan nilai mata kuliah geometri bidang kategori rendah. Berdasarkan Gambar 10., M10 mampu memahami tentang apa masalahnya dan apa yang ditanyakan, mampu menentukan strategi untuk menyelesaikan masalah. Mampu menjalankan rencana. Sehingga dapat memperoleh jawaban dari permasalahan yang diajukan. Namun terdapat operasi hitung pada tahap menjalankan rencana (ditandai dengan warna merah). Sehingga jawaban yang diperoleh tidak tepat. Mahasiswa tidak memeriksa solusi apakah hasilnya logis dan benar.

Rekap dari hasil analisis jawaban mahasiswa calon guru, berdasarkan tahapan pemecahan masalah Polya dapat dilihat pada Tabel 2. 
DOI: https://doi.org/10.24127/ajpm.v10i3.3717

Table 2. Rekap hasil analisis jawaban tes pemecahan masalah berdasarkan tahapan Polya

\begin{tabular}{|c|c|c|c|c|c|c|}
\hline \multirow[t]{2}{*}{ Subjek } & \multirow{2}{*}{$\begin{array}{l}\text { Kategori nilai } \\
\text { geometri } \\
\text { bidang }\end{array}$} & \multicolumn{4}{|c|}{$\begin{array}{l}\text { Tahapan pemecahan } \\
\text { masalah Polya }\end{array}$} & \multirow[t]{2}{*}{ Deskripsi } \\
\hline & & 1 & 2 & 3 & 4 & \\
\hline 1 & Tinggi & $\sqrt{ }$ & $\sqrt{ }$ & $\sqrt{ }$ & $\mathrm{X}$ & $\begin{array}{l}\text { Memperoleh solusi, namun salah operasi } \\
\text { hitung bentuk aljabar dan tidak } \\
\text { memeriksa kembali }\end{array}$ \\
\hline 2 & Tinggi & $\sqrt{ }$ & $\sqrt{ }$ & $\sqrt{ }$ & $\mathrm{X}$ & $\begin{array}{l}\text { Memperoleh solusi } \text { dan } \\
\text { perhitungan benar. } \\
\text { memeriksa kembali }\end{array}$ \\
\hline 3 & Tinggi & $\sqrt{ }$ & $\sqrt{ }$ & $\sqrt{ }$ & $X$ & $\begin{array}{l}\text { Memperoleh solusi } \text { dan } \\
\text { perhitungan benar. } \\
\text { memeriksa kembali }\end{array}$ \\
\hline 4 & Tinggi & $\sqrt{ }$ & $\sqrt{ }$ & $\sqrt{ }$ & $X$ & $\begin{array}{l}\text { Tidak memperoleh solusi atas } \\
\text { pertanyaan yang ditanyakan, kurang } \\
\text { teliti dalam membaca apa yang } \\
\text { ditanyakan dan tidak memeriksa } \\
\text { kembali }\end{array}$ \\
\hline 5 & Tinggi & $\sqrt{ }$ & $\sqrt{ }$ & $\sqrt{ }$ & $X$ & $\begin{array}{l}\text { Tidak memperoleh solusi atas } \\
\text { pertanyaan yang ditanyakan, karena } \\
\text { kesulitan operasi bentuk akar }\end{array}$ \\
\hline 6 & Sedang & $\sqrt{ }$ & $\sqrt{ }$ & $\sqrt{ }$ & $X$ & $\begin{array}{l}\text { Memperoleh solusi, namun salah operasi } \\
\text { hitung bentuk aljabar dan tidak } \\
\text { memeriksa kembali }\end{array}$ \\
\hline 7 & Sedang & $\sqrt{ }$ & $\sqrt{ }$ & $\sqrt{ }$ & $X$ & 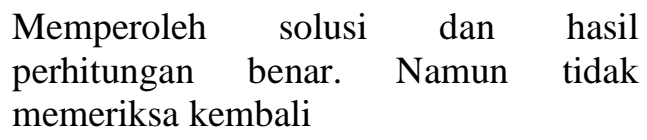 \\
\hline 8 & Sedang & $\sqrt{ }$ & $\sqrt{ }$ & $\sqrt{ }$ & $X$ & $\begin{array}{l}\text { Memperoleh solusi, namun salah operasi } \\
\text { hitung dan tidak memeriksa kembali }\end{array}$ \\
\hline 9 & Rendah & $X$ & $\mathrm{X}$ & $\mathrm{X}$ & $X$ & $\begin{array}{l}\text { Tidak memahami konsep diagonal, lupa } \\
\text { rumus luas layang-layang, berasumsi } \\
\text { luas adalah hasil perkalian sisi }\end{array}$ \\
\hline 10 & Rendah & $\sqrt{ }$ & $\sqrt{ }$ & $\sqrt{ }$ & $X$ & $\begin{array}{l}\text { Memperoleh solusi, namun salah. } \\
\text { Karena melakukan kesalahan operasi } \\
\text { hitung dan tidak memeriksa kembali }\end{array}$ \\
\hline
\end{tabular}

Hasil penelitian menunjukkan bahwa, secara keseluruhan dalam penyelesaian soal pemecahan masalah mahasiswa calon guru tidak memeriksa solusi dan tidak memeriksa apakah hasilnya logis dan benar (tahap 4). Hal ini sejalan dengan penelitian (Pratiwi et al., 2019) yang menyatakan bahwa seluruh subjek penelitian tidak ada yang memeriksa kembali solusi yang diperoleh. (Yayuk \& Husamah, 2020) menyatakan bahwa kemampuan pemecahan masalah mahasiswa calon guru berdasarkan tahapan Polya relatif lemah, mahasiswa calon guru kesulitan pada tahapan mengecek kembali.

Selain itu, beberapa mahasiswa mengalami kesulitan dalam operasi hitung. (Barham, 2019) menyatakan bahwa mahasiswa lemah dalam menerapkan berbagai keterampilan yang dibutuhkan untuk sukses dalam pemecahan masalah, seperti menafsirkan informasi, doing mathematics, dan berpikir logis. 
DOI: https://doi.org/10.24127/ajpm.v10i3.3717

Berdasarkan kategori nilai geometri bidang, mahasiswa dengan kategori tinggi, dari 5 orang terdapat 2 orang mahasiswa mampu menjalankan rencana (tahap 3) dengan baik, sehingga memperoleh solusi yang benar, meski tidak memeriksa kembali solusi yang diperolehnya. Hasil penelitian ini sejalan dengan hasil penelitian (Pratiwi et al., 2019) bahwa mahasiswa dengan kategori tinggi, tidak melakukan pengecekan kembali. 1 orang mahasiswa melakukan kesalahan operasi bentuk alajabar dalam menjalankan rencana (tahap 3) sehingga tidak diperoleh solusi yang benar. Salah satu faktor penyebab kesalahan dalam pemecahan masalah adalah kelemahan dalam operasi hitung (Harahap, Muchlis, \& Maulidiya, 2019). 1 orang mahasiswa tidak membaca apa yang ditanyakan dengan baik dan 1 orang mahasiswa kesulitan dalam menjalankan rencana, karena kesuliutan operasi akar. Ketidaktelitian dalam membaca soal, menjadi salah satu faktor penyebab kesahalan dalam pemecahan masalah (Harahap et al., 2019).

Berdasarkan kategori nilai geometri bidang, mahasiswa dengan kategori sedang, dari 3 orang, 1 orang mahasiswa mampu menjalankan rencana (tahap 3) dengan baik, sehingga memperoleh solusi yang benar, meskipun tidak melakukan pengecekan kembali. Hal ini sejalan dengan penelitian (Pratiwi et al., 2019). Sedangkan 2 orang mahasiswa melakukan kesalahan operasi hitung dalam menjalankan rencana (tahap 3) sehingga tidak diperoleh solusi yang benar. Keterampilan operasi hitung menjadi faktor dari keberhasilan pemecahan masalah (Harahap et al., 2019; Punding, 2019)

Berdasarkan kategori nilai geometri bidang, mahasiswa dengan kategori rendah, 1 orang mahasiswa mampu memahami dan membuat rencana namun melakukan kesalahan operasi hitung dalam menjalankan rencana (tahap 3) sehingga tidak diperoleh solusi yang benar. Sedangkan 1 orang mahasiswa tidak memahami masalah dengan baik, karena tidak memahami konsep diagonal dan luas. Pemahaman konsep sangat dibutuhkan dalam pemecahan masalah (Khoirunnisa et al., 2020; Sari \& Aripin, 2018). Menurut (Mulyana, Turmudi, \& Juandi, 2014) kelemahan penguasaan konsep dapat diatasi dengan melakukan pendalaman materi.

Yee \& Hoe menyatakan bahwa kemampuan pemecahan masalah seseorang dapat dipengaruhi oleh faktor kognitif, afektif dan pengalaman seseorang (Masfingatin et al., 2018). Berdasarkan hasil wawancara terkait pengalaman belajar materi segiempat di sekolah dan di universitas baik siswa dengan skor geometri bidang kategori tinggi, sedang maupun rendah, memiliki pengalaman belajar yang serupa.

Berdasarkan hasil tes pemecahan masalah calon guru dengan skor mata kuliah geometri bidang kategori tinggi pun masih melakukan kesalahn operasi, maka perlu banyak berlatih dalam mengerjakan soal soal pemecahan masalah dan mengulang kembali pemahaman konsep dari topik materi pemecahan masalah (Afdila \& Roza, 2018). Menurut (Masfingatin et al., 2018) kemampuan pemecahan masalah dapat dilatih dengan memperbanyak pengalaman dalam pemecahan masalah, yaitu dengan lebih sering melakukan pemecahan masalah. Lebih lanjut (Masfingatin et al., 2018). Agar dapat memiliki banyak pengalaman pemecahan masalah seseorang harus memiliki kemauan atau motivasi untuk melakukan pemecahan masalah. 
DOI: https://doi.org/10.24127/ajpm.v10i3.3717

Selain faktor kognitif, afektif dan pengalaman, faktor lingkungan pembelajaran juga dapat mempengaruhi startegi siswa untuk mencari solusi pemecahan masalah. Selain menggunakan paper-and-pencil, teknologi dapat dijadikan alat bantu dalam mengembangkan kemampuan pemecahan masalah (Koyuncu, Akyuz, \& Cakiroglu, 2014). (Fadzil, 2017) menyatakan bahwa pendekatan inkuiri sosiologi merupakan salah satu pendekatan pembelajaran yang berguna dalam pendidikan guru untuk mendukung calon guru dalam proses pemecahan masalah.

Hasil peneitian ini dapat memberikan gambaran terkait kemampuan pemecahan masalah calon guru tingkat akhir. Berdasarkan hasil penelitian ini, dosen pembimbing dari 10 mahasiswa tersebut dapat membuat strategi bimbingan agar 10 mahasiswa tersebut dapat memiliki penguasaan konten pada materi segiempat, sebagai materi penelitian mahasiswa.

Selain itu, hasil ini dapat dijadikan landasan dalam upaya mengembangkan kemampuan pemecahan masalah calon guru matematika, yang merupakan salah satu kemampuan yang menunjang kompetensi guru. Dapat dijadikan bahan pertimbangan pemilihan strategi, media pembelajaran selama proses permbelajaran di semua mata kuliah.

\section{KESIMPULAN DAN SARAN}

Berdasarkan paparan hasil dan pembahasan, seluruh mahasiswa, baik skor mata kuliah geometri bidang kategori tinggi, sedang, maupun rendah tidak melakukan pengecekan kembali. Hasil penelitian menunjukkan bahwa kemampuan pemecahan masalah mahasiswa baik dikategori tinggi, sedang maupun rendah masih berada pada tahap 3 menjalankan rencana. 30\% mahasiswa mampu menjalankan rencana dengan baik, sehingga memperoleh solusi yang tepat, meskipun tidak melakukan pengecekan kembali. $\quad 40 \%$ mahasiswa mampu menjalankan rencana, namun melakukan kesalahan operasi hitung, sehingga solusi yang diperoleh tidak tepat. $10 \%$ mahasiswa tidak mampu menjalankan rencana karena kesulitan operasi hitung. $10 \%$ mahasiswa tidak teliti dalam membaca apa yang ditanyakan di soal. $10 \%$ mahasiswa salah memahami masalah, karena Tidak memahami konsep diagonal, lupa rumus luas layang-layang, berasumsi luas adalah hasil perkalian sisi.

Terdapat mahasiswa calon guru kategori skor mata kuliah geometri bidang tinggi, sedang maupun rendah yang melakukan kesalahan operasi hitung sehingga solusi yang diberikan tidak tepat. Karena tidak memeriksa kembali apakah solusi yang diperoleh logis dan benar atau tidak. Mereka tidak menyadari solusi yang diperoleh dari tahap menerapkan rencana tersebut salah. Terdapat mahasiswa kategori rendah yang tidak memahami masalah karena tidak memahami konsep diagonal dan luas layang - layang.

Hasil penelitian ini akan digunakan untuk landasan penelitian selanjutnya yakni mendesain lintasan belajar dalam proses bimbingan skripsi mahasiswa calon guru sekolah menengah yang akan penelitian skripsi pada materi segiempat. Setelah mendesain lintasan belajar dan divalidasi, hasilnya akan diimplementasikan dalam proses bimbingan skripsi.

Berdasarkan hasil penelitian ini, diharapkan penelitian selanjutnya dapat berupa upaya untuk meningkatkan kemampuan pemecahan masalah mahasiswa calon guru tingkat menengah. 


\section{DAFTAR PUSTAKA}

Afdila, N. F., \& Roza, Y. (2018). Analisis kesalahan siswa dalam menyelesaikan masalah konstekstual materi bangun ruang sisi datar berdasarkan tahapan Kastolan. LEMMA : Letters of Mathematics Education, 5(1), 6572.

Barham, A. I. (2019). Investigating the Development of Pre-Service Teachers' Problem-Solving Strategies via Problem-Solving Mathematics Classes. European Journal of Educational Research, 9(1), 129-141. https://doi.org/10.12973/eujer.9.1.129

Fadzil, H. M. (2017). Exploring early childhood preservice teachers , problem-solving skills through socioscientific inquiry approach. Asia-Pacific Forum on Science Learning and Teaching, 18(1), 120.

Harahap, Z. I. S., Muchlis, E. E., \& Maulidiya, D. (2019). Faktor faktor penyebab kesalahan siswa dalam menyelesaikan soal luas permukaan kubus dan balok. Jurnal Penelitian Pembelajaran Matematika Sekolah (JP2MS), 3(3), 342-352.

Iqbal, T., \& Akbar, R. (2020). Pelatihan Internet dan Powerpoint untuk Guru-Guru di Sekolah Dasar Negeri 19 Kota Sabang. BAKTI BANUA : Jurnal Pengabdian Kepada Masyarakat, 1(1), 18-24.

Khoirunnisa, S., Sulhan, Kalsum, U., Timbu, D. L., Ngongo, O. B., \& Ambarawati, M. (2020). Analisis kesulitan siswa dalam menyelesaikan soal matematika materi luas permukaan dan volume bangun ruang sisi datar. Prismatika: Jurnal Pendidikan
Dan Riset Matematika, 2(2), 2132.

Koyuncu, I., Akyuz, D., \& Cakiroglu, E. (2014). Investigasi plane geometry problem-solving startegies of prospective mathematics teachers in technology and paper-and-pencil environments. International Journal of Science and Mathematics Education, 13, 837862.

https://doi.org/10.1007/s10763014-9510-8

Leong, K. E., Chew, C. M., \& Rahim, S. S. A. (2015). Understanding Malaysian Pre-Service Teachers Mathematical Content Knowledge and Pedagogical Content Knowledge. Eurasia Journal of Mathematics, Science and Technology Education, 11(3), 363-370. https://doi.org/10.12973/eurasia.2 $015.1346 \mathrm{a}$

Masfingatin, T., Murtafiah, W., \& Krisdiana, I. (2018). Prospective Student Teachers Of Mathematics Abilities In Problem Solving Geometry Theorem Proving. Jurnal Mercumatika: Jurnal Penelitian Matematika Dan Pendidikan Matematika, 2(2), 4150.

Mulyana, E., Turmudi, \& Juandi, D. (2014). Model pengembangan desian didaktis subject specific pedagogy bidang matematika melalui program pendidika profesi guru. Jurnal Pengajaran MIPA, 19(2), 141-149.

National Council for Accreditation of Teacher Education (NCATE). (2008). Professional standards for the accreditation of teacher preparation institutions. washington DC: NCATE. 
Nugroho, A., \& Dwijayanti, I. (2019). Analisis Kemampuan Pemecahan Masalah Mahasiswa Calon Guru Matematika Pada Mata Kuliah Program Linier. AKSIOMA: Jurnal Matematika Dan Pendidikan Matematika, 10(2), 277-284.

Pratiwi, D., Santi, D., \& Maharani, A. (2019). Kemampuan pemecahan masalah matematis mahasiswa calon guru sekolah dasar dalam menyelesaikan soal cerita berbasis karakter pada materi bilangan pecahan A . PENDAHULUAN Matematika sebagai ratu dan pelayannya ilmu dapat membantu memecahkan permasalahan manu. Premiere Educandum: Jurnal Pendidikan Dasar Dan Pembelajaran, 9(2), 194-202. https://doi.org/10.25273/pe.v9i2.5 110

Punding, W. (2019). Punding: Identifikasi Kesalahan Siswa dalam Menyelesaikan Soal Lingkaran. Jurnal Pendidikan, 19(2), 129-142.

Saputro, B. A., \& Sumarni, S. (2017). Desain Pembelajaran Garis Bagi Sudut Dengan Pendekatan Matematika Realistik. AKSIOMA: Jurnal Program Studi Pendidikan Matematika, 6(1), 136. https://doi.org/10.24127/ajpm.v6i 1.915

Sari, A. R., \& Aripin, U. (2018). Analisis Kesalahan Siswa dalam Menyelesaikan Soal Cerita Bangun Datar Segiempat ditinjau dari Kemampuan Pemecahan Masalah Matematik untuk Siswa Kelas VII. Jurnal Pembelajaran Matematika Inovatif, 1(6), 11351142.

Sumarni, Darhim, \& Fatimah, S. (2020). Didactic trajectory of learning device development using projectbased learning. Journal of Physics: Conference Series, 1470(1).

https://doi.org/10.1088/17426596/1470/1/012065

Sumarni, Darhim, Fatimah, S., Widodo, S., \& Riyadi, M. (2019). Mathematics Content Knowledge Prospective Teachers Through Project-Based Learning Assisted By GeoGebra 5.0. In ICSTI 2018 (p. 2281289). https://doi.org/10.4108/eai.19-102018.2281289

Sumarni, S., Darhim, D., \& Siti, F. (2019). Profile of mathematical knowledge for teaching of prospective mathematics teachers in develop the lesson plan. Journal of Physics: Conference Series, 1157(4). https://doi.org/10.1088/17426596/1157/4/042107

Tanujaya, B., Mumu, J., \& Margono, G. (2017). The Relationship between Higher Order Thinking Skills and Academic Performance of Student in Mathematics Instruction. International Education Studies, 10(11), 78-85. https://doi.org/10.5539/ies.v10n11 p78

Tatto, M. T., Banvok, K., Becker, A., Brese, F., Byun, S.-Y., Carstens, R., ... Yu, A. (2013). The Teacher Education and Development Study in Mathematics (TEDS-M): Policy, Practice, and Readiness to Teach Primary and Secondary Mathematics in 17 Countries. Technical Report. https://doi.org/10.1038/nn.2116

Tatto, M. T., \& Senk, S. (2011). The mathematics education of future primary and secondary teachers: Methods and findings from the 
DOI: https://doi.org/10.24127/ajpm.v10i3.3717

teacher education and development study in mathematics. Journal of Teacher Education, 62(2), 121-137. https://doi.org/10.1177/00224871 10391807

Usta, N. (2020). Evaluation of Preservice Teachers ' Skills in Solving Non-Routine Mathematical Problems through Various Strategies. Asian Journal of Education and Training, 6(3), 362-383.

https://doi.org/10.20448/journal.5 22.2020.63.362.383

Yayuk, E., \& Husamah, H. (2020). The Difficulties of Prospective Elementary School Teachers in Item Problem Solving for Mathematics: Polya', s Steps. Journal for the Education of Gifted Young Scientists, 8(March), 361-378. 